\title{
Варіативність кореляції рівня функції та спастичності паретичної кінцівки за різного перебігу відновного процесу на моделі спінальної травми
}

\author{
V. V. MEDVEDIEV \\ National Academy of Medical Sciences of Ukraine, A. Romodanov Institute of Neurosurgery
}

\section{THE VARIABILITY OF THE PARETIC LIMB FUNCTION AND SPASTICITY CORRELATION FOR VARIOUS RESTORATIVE PROCESS FLOW ON THE SPINAL CORD INJURY MODEL}

\begin{abstract}
Метою роботи було дослідження кореляції рівня спастичності та функції паретичної кінцівки на моделі спінальної травми. Тварини - білі безпородні щури-самці (5,5 міс. 350 г), групи: “контроль” - лівобічний перетин половини поперечника спинного мозку на рівні $\mathrm{T}_{11}(\mathrm{n}=16)$, “стороннє тіло” - аналогічна травма + негайна імплантація фрагмента мікропористого гідрогелю в зону ураження спинного мозку $(\mathrm{n}=10)$; “нейрогель” - імплантація фрагмента NeuroGel $^{\mathrm{TM}}$ за аналогічних умов $(\mathrm{n}=20)$. Дослідження показника функції (ПФ) та показника спастичності (ПС) задньої іпсилатеральної кінцівки (ЗІК) - шкала Basso-Beattie-Bresnahan (BВB) та шкала Ashworth відповідно. Імплантація фрагмента NeuroGel ${ }^{\mathrm{TM}}$ достовірно покращує результативність відновного процесу на 7 балів шкали ВВВ, зменшує рівень спастичності на 1 бал шкали Ashworth; персистенція стороннього тіла - погіршує перебіг травматичного процесу протягом 2-4-го місяця, достовірно зменшуючи ПФ та збільшуючи ПС ЗІК. У групах “контроль” та “нейрогель”, на відміну від групи “стороннє тіло”, ПФ та ПС ЗІК не виявляють сильної від’ємної кореляції (r>-0,75); для групи “нейрогель” виявлено додатну кореляцію ПС та ПФ при аналізі динаміки їх значень у часі. Регенераційний процес суттєво видозмінює вид кореляції між рівнем функції та спастичності паретичної кінцівки, ймовірно, шляхом збільшення елементної бази еферентної ланки рухової системи, контрольованої супраспінальними впливами.

The goal of the work - to explore the correlation of spasticity and function level of paretic limbs on the spinal cord injury model. Animals - white inbred male rats (5.5 months, 350 g); groups: “control” - the left-side spinal cord hemisection at $T_{11}(n=16)$, "foreign body" - immediate implantation of fragment of the microporous hydrogel in the locus of spinal cord injury ( $n=10)$; “neurogel” - implantation of the NeuroGel ${ }^{\mathrm{TM}}$ fragment under similar conditions $(\mathrm{n}=20)$. Monitoring of the ipsilateral hind limb (IHL) function and spasticity indicator (FI and SI respectively) - Basso-Beattie-Bresnahan (BBB) scale and Ashworth scale, respectively. Implantation of NeuroGel ${ }^{\mathrm{TM}}$ significantly improves the efficiency of the functional recovery by 7 points of BBB scale, reduces spasticity by 1 point of Ashworth scale. Foreign body persistence worsens the course of the traumatic process during the $2^{\text {nd }}-4^{\text {th }}$-month, significantly reduce IHL FI and increase SI. IHL FI and SI in groups “control” and "neurogel”, unlike the group "foreign body", do not show a strong negative correlation $(r>-0.75)$. In the group "neurogel" we found a positive correlation between IHL FI and SI during the observation period. Spinal cord regeneration significantly modifies IHL FI and SI correlation, probably by increasing the number of motoneurons effectively controlled by supraspinal influences.
\end{abstract}

Постановка проблеми і аналіз останніх досліджень та публікацій. Незважаючи на значну біомедичну та соціально-економічну вагу проблеми спінальної травми [1-3], тривалу зацікавленість наукової спільноти питаннями відновлення функції ураженого спинного мозку [4-7], багато питань цього кола залишаються невивченими. Травма спинного мозку перебуває в авангарді сучасної біотехнологічної галузі, до її вирішення залучаються найновіші розробки біонічного (нейропротезування, екзоскелетування) [8-10], біогенного (тканинна нейроінженерія) [11-14] та комплексного [15] характеру. Одними із найскладніших, з патофізіологічної точки зору, питань $€$ механізми формування синдрому спастичності, який виявляють у 45-78 \% спінальних хворих [16-19]. Попри значний прогрес у цьому напрямку [20-23], недостатньо вивченими залишаються питання щодо динаміки спастичності при різноманітних видах експериментальної травми спинного мозку [24-29], її співвідношення 3 динамікою відновлення функції. Останній момент, попри вдавану очевидність, у сучасних експериментальних роботах, присвячених скру- 
пульозному аналізу клініки однотипних варіантів спінальної травми, не висвітлений [30-36]. Ряд даних вказує на паралелізм механізмів спастичності та відновлення функції мотонейронів спинного мозку після спінального шоку [37], на ранніх етапах спінальної травми ці два механізми, найімовірніше, ідентичні; нейропластичний процес на цих термінах спінальної травми має амбівалентну результативність - сприяючи відновленню чутливості мотонейронів до вцілілих супраспінальних впливів, створюються передумови для формування різноманітних форм спінальної дисрефлексії, у тому числі спастичності.

Зважаючи на це, вивчення кореляції динаміки спастичності та функції паретичної кінцівки за різних видів травматичного ураження спинного мозку та на тлі відновних втручань $є$ актуальним, що зумовило проведення даного дослідження.

Матеріали і методи. Дослідження виконано 3 дотриманням існуючих норм біоетики на білих безпородних щурах-самцях (ДУ “Інститут нейрохірургї імені А. П. Ромоданова НАМН України”), віком 5,5 міс., масою 350 г, утримуваних у стандартних умовах, за звичного харчування. Експериментальні групи: “контроль” - моделювання травми спинного мозку $(n=16)$; “стороннє тіло” імплантація фрагмента мікропористого гідрогелю в зону ураження спинного мозку відразу після моделювання спінальної травми $(n=10)$; “нейрогель” - імплантація в зону ураження спинного мозку фрагмента NeuroGel ${ }^{\mathrm{TM}}$ за аналогічних умов $(n=20)$.

NeuroGel $^{\mathrm{TM}}$ (полі[N-(2-гідроксипропіл)-метакриламід]) - комерційний препарат, синтезований у лабораторії E. Pinet (FISO Technologies Inc., Quebec, Canada) шляхом гетерогенної полімеризації, на даний час один із найбільш ефективних матриксів для регенерації спинного мозку [38]. Як стороннє тіло використовували цільний фрагмент гідрогелю з аналогічною первинною хімічною структурою, однак вищим коефіцієнтом просторової щільності.

Особливості використаної моделі спінальної травми (лівобічне пересічення половини поперечника спинного мозку) описані нами у попередній роботі [39], у загальних рисах - після поздовжнього розтину шкіри знеболеної ${ }^{1}$ тварини на проміжку, достатньому для скелетування остистих відростків $\mathrm{T}_{9}-\mathrm{L}_{1}$, виконували ламінектомію на рівні $\mathrm{T}_{11}$, списоподібним офтальмологічним скальпелем тканину спинного мозку наскрізно проколювали у дорзо-вентральному напрямку біля лівого краю задньої серединної судини, у рану заводили одну з бранш офтальмологічних ножиць, другою охоплювали і перетинали ліву половину спинного мозку. Тваринам групи “стороннє тіло” у рану спинного мозку імплантували фрагмент мікропористого гідрогелю розміром 1 мм³ , тваринам групи “нейрогель” - фрагмент NeuroGel ${ }^{\mathrm{TM}}$ аналогічного об’єму; тваринам усіх груп зону ламінектомії укривали фрагментом підшкірної фасції, м’які тканини та шкіру з’єднували крученими поліамідними хірургічними нитками (ум. № 1, ПАТ “Київхімволокно”) у два ряди вузлових швів, ділянку рани обробляли 5 \% спиртовим розчином йоду. У задню шийну ділянку підшкірно вводили розчин біциліну-5 (ПАТ “Київмедпрепарат”; 150200 тис. ОД на 1 тварину), внутрішньоочеревинно - розчин дексаметазону (KRKA, Словенія; 6 мг/ кг). Після вказаних маніпуляцій тварин протягом 2-4 год утримували в приміщенні з підвищеною температурою повітря $\left(30^{\circ} \mathrm{C}\right)$, надалі - y клітках по 3-6 особин при середній температурі 21-24 ${ }^{\circ} \mathrm{C}$. Тривалість спостереження для усіх тварин складала 24 тижні; виведення тварин з експерименту здійснювали шляхом передозування вказаних вище наркотичних препаратів.

Показник функції (ПФ) задньої іпсилатеральної щодо зони травми кінцівки (ЗІK) оцінювали згідно зі шкалою, запропонованою D. M. Basso, M. S. Beattie та J. C. Bresnahan (BВB) [39]. Показник спастичності (ПС) на рівні надп’ятковогомілкового та колінного суглобів ЗІК оцінювали за шкалою В. Ashworth [24-26, 31]. Протягом перших 2-х місяців реєстрували ПФ та ПС ЗІК наприкінці кожного тижня, у подальшому - наприкінці кожного місяця.

Статистичну обробку отриманих даних здійснювали у програмному пакеті STATISTICA 10.0. Порівняння результатів моніторингу ПФ та ПС ЗІК в експериментальних групах здійснювали непараметричним U-тестом Манна-Уїтні (Mann-WhitneyU-test), результати представляли у вигляді значень показника $p$ зі звичним їх трактуванням. Достовірність різниці ПФ та ПС 3ІК на різних термінах спостереження кожної окремо взятої групи оцінювали за Уілкоксоном (Wilcoхоn), оцінку зв'язку і спрямованості змін - на основі рангового коефіцієнта Спірмена (Srearman). Кореляцію між значеннями ПС та ПФ ЗІК тварин групи на кожному з термінів дослідження, на різних термінах спостереження кожної тварини, а також середніх по групі значень ПФ та ПС ЗІК впродовж експерименту оцінювали за допомогою непараметричного ко-

\footnotetext{
${ }^{1}$ Внутрішньоочеревинне введення суміші розчинів ксилазину (“Sedazin”, “Biowet”, Польща; 15 мг/кг) та кетаміну (“Calypsol”, “Гедеон Ріхтер А. О.”, Угорщина; 70 мг/кг).
} 
ефіцієнта рангової кореляції Спірмена (Srearman) та параметричного коефіцієнта кореляції Пірсона (Pearson), результати оцінки виражали у вигляді значення коефіцієнта $r$ зі звичним їх трактуванням.

Результати досліджень та їх обговорення. Динаміка ПФ ЗІК у групі “контроль” (рис. 1, а) характеризується двофазністю: протягом 1-го місяця відмічали збільшення $(\mathrm{p}<0,01)$ ПФ ЗІК до $(1,66 \pm 0,54)$ бала ВВВ, у подальшому - рівновеликий регрес, повторне збільшення $(\mathrm{p}<0,05)$ і стабілізацію (24-й тиждень - $(1,59 \pm 0,49)$ бала ВВВ). Максимальний приріст $(\mathrm{p}<0,05)$ значень ПС ЗІК (до $(1,8 \pm 0,3)$ бала Ashworth) у групі спостерігали протягом 1-го місяця; максимум реєстрували на 20 -му тижні $((2,6 \pm 0,4)$ бала), у подальшому достовірні зміни показника не виявляли.

ПФ ЗІК у групі “стороннє тіло” (рис. 1, б) станом на 7-му добу складав $(1,7 \pm 0,9)$ бала ВВВ, до кінця 8-го тижня ПФ ЗІК перебував на рівні $(1,30 \pm 0,94)$ бала ВВВ, у період з 12-го до 16-го тижня збільшувався $(\mathrm{p}<0,05)$ до $(2,5 \pm 0,84)$ бала, станом на кінець 24-го тижня складав $(2,35 \pm 0,95)$ бала ВВВ. На 7-му добу експерименту ПС ЗІК у групі становив $(2,3 \pm 0,11)$ бала Ashworth, перевищував $(\mathrm{p}<0,01)$ показники груп “нейрогель” та “контроль”; збільшувався до $(3,6 \pm 0,2)$ бала Ashworth протягом 45 -го тижня, у подальшому зменшувався $(\mathrm{p}<0,05)$
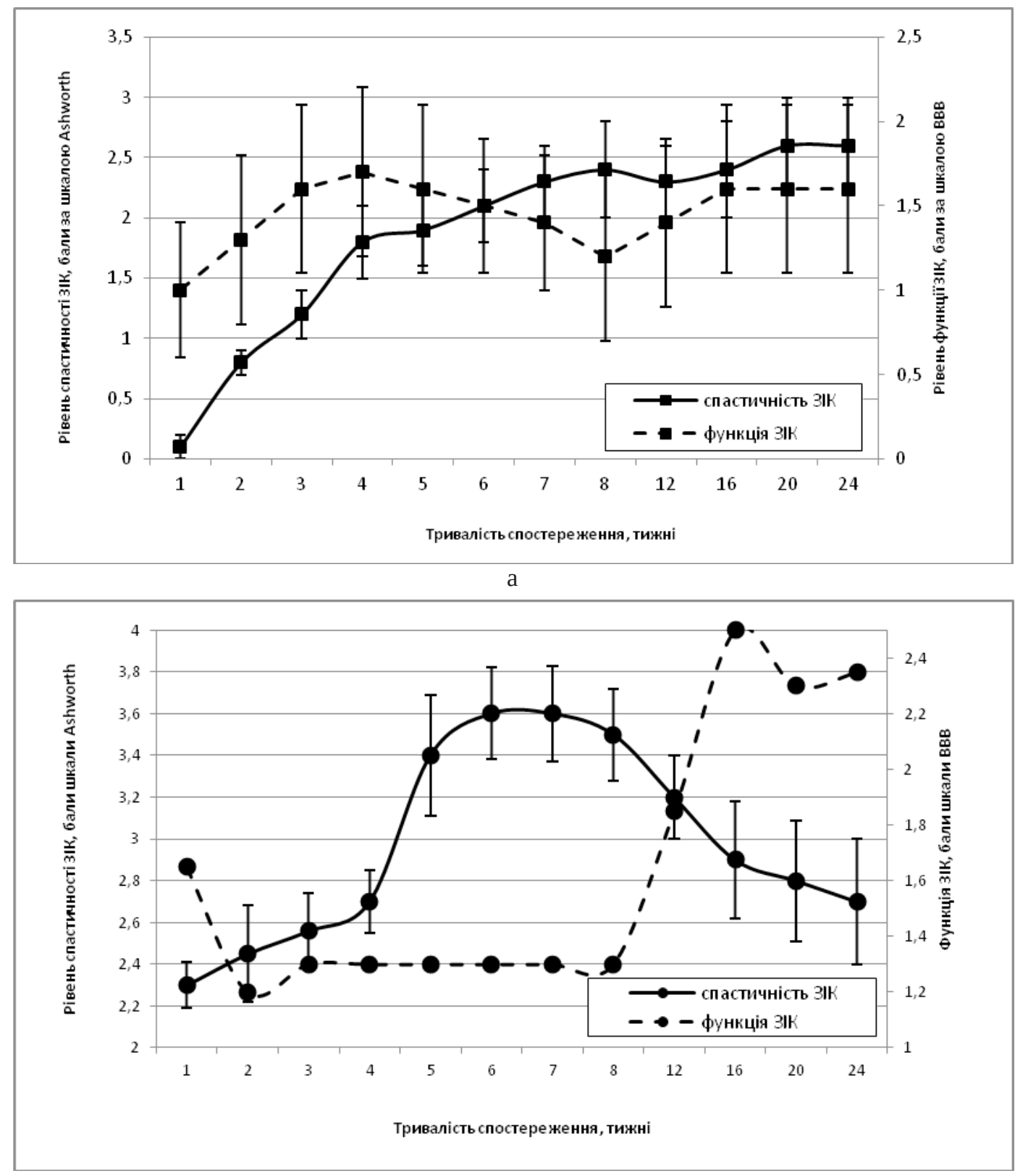

б

Рис. 1. Зіставлення в часі динаміки ПФ та ПС ЗІК у групі “контроль” (а), “стороннє тіло” (б, планки погрішностей значень ПФ не наводимо). 


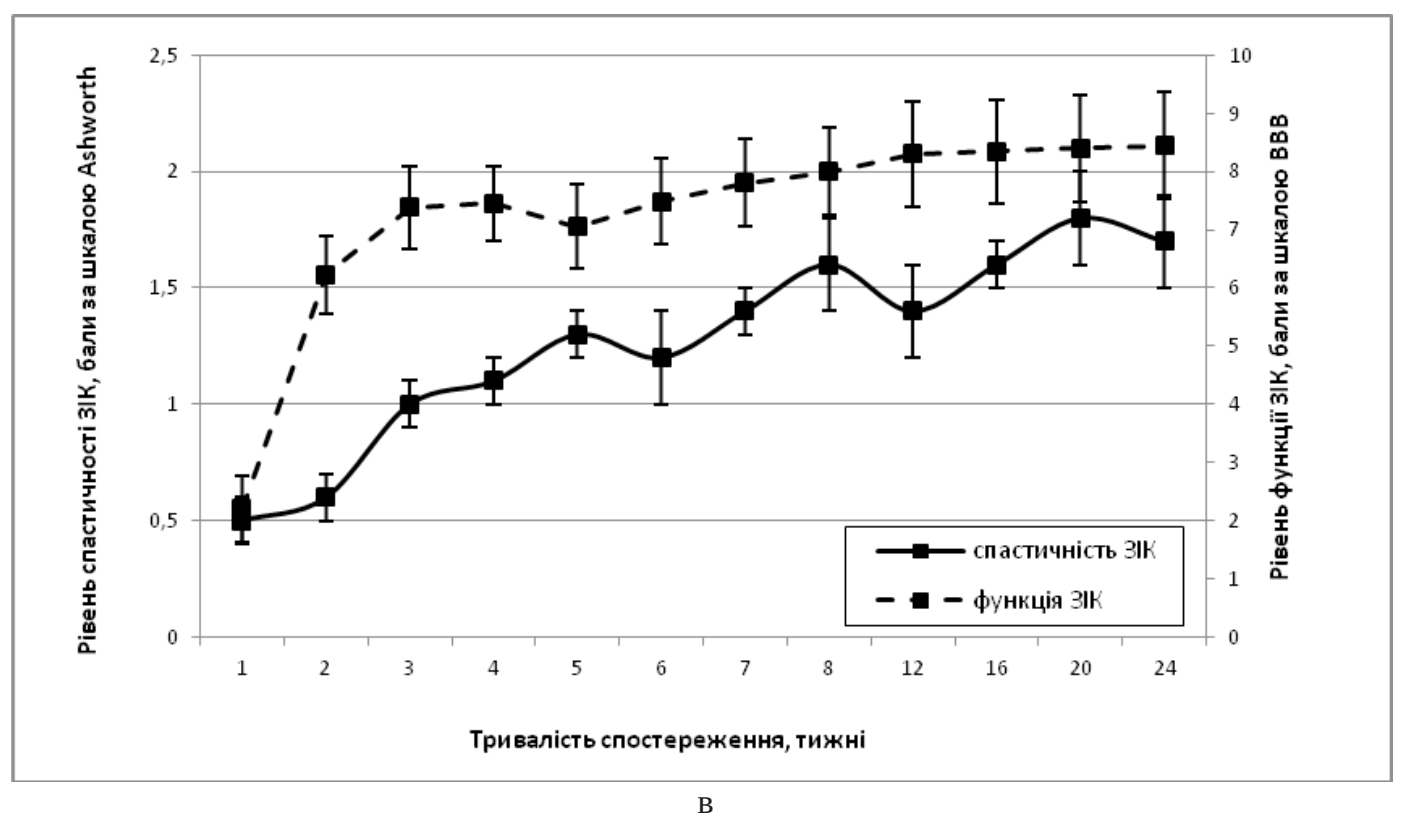

Рис. 1 (продовження). Зіставлення в часі динаміки ПФ та ПС ЗІК у групі “нейрогель” (в).

до рівня $(2,7 \pm 0,3)$ бала. Протягом 3-4-го місяців експерименту різниця між ПС ЗІК груп “стороннє тіло” та “контроль” була недостовірною.

Динаміка ПФ ЗІК групи “нейрогель” (рис. 1, в) двофазна (1-5-й тиждень, 5-26-й тиждень); ПФ ЗІК наприкінці 4-го місяця становив $(8,35 \pm 0,89)$ бала, наприкінці експерименту - $(8,45 \pm 0,92)$ бала ВВВ. Різниця ПФ ЗІК між групами “нейрогель” та “стороннє тіло”, починаючи з 3-го тижня експерименту, складала близько 6-ти балів ВВВ $(\mathrm{p}<0,01)$. Динаміка ПС ЗІК у групі “нейрогель” трифазна: швидке збільшення $(p<0,05)$ протягом 1-го місяця, стабілізація (4-6-й тиждень), друга фаза швидкого збільшення (6-8-й тиждень; $p<0,05)$, стабілізація (8-16-й тиждень), третя фаза збільшення (16-20-й тиждень; $p<0,05)$, прикінцева стабілізація (20-24-й тиждень). Станом на 24-й тиждень спостереження ПС ЗІК склав $(1,7 \pm 0,2)$ бала Ashworth, різницю $(p<0,05)$ значень ПС 3ІК між групами “контроль” та “нейрогель” відмічали протягом 5-7-го та 12-24-го тижня.

При аналізі кореляції індивідуальних значень ПФ та ПС ЗІК кожної тварини на різних термінах спостереження у групі “контроль” виявлено 3 із 16 особин (18,8 \%) з помірною та сильною від’ємною кореляцією ( $\mathrm{r}=-0.69,-0.84$ та -0.64 відповідно), у групі “стороннє тіло” - 1 особина (10 \%) із сильною від'ємною кореляцією (r= $-0,75)$, у групі “нейрогель” - 4 особини (20 \%) з помірною та сильною додатною кореляцією ( $\mathrm{r}=0.73,0.69,0.62$ та 0.64 відповідно).

При аналізі кореляції індивідуальних значень ПФ та ПС ЗІК різних тварин на кожному з термінів спостереження у групі “контроль” виявлено помірну та сильну від’ємну кореляцію $(\mathrm{r}<-0,5)$ на 3-6-му та 8-24-му тижнях, у групі “стороннє тіло” - сильну $(r \leq-0,75)$ та помірну $(-0,75<\mathrm{r} \leq-0,65)$ від'ємну кореляцію на 1-му, 3-7-му, 16-му, 24-му та 8-му, 12-му, 20-му тижнях відповідно, у групі “нейрогель” - сильну $(\mathrm{r} \leq-0,75)$ та помірну $(-0,75<\mathrm{r} \leq-0,65)$ від'ємну кореляцію на 12-24-му та 3-8-му тижнях відповідно.

При аналізі кореляції середніх по групі значень ПФ та ПС ЗІК на різних термінах спостереження для групи “контроль” виявлено слабку додатну кореляцію ( $\mathrm{r}=0,34$ за Спірменом та $\mathrm{r}=0,60$ за Пірсоном), для групи “стороннє тіло” - слабку від’ємну кореляцію ( $r=0,07$ за Спірменом та $\mathrm{r}=0,26$ за Пірсоном), для групи “нейрогель” - сильну додатну кореляцію (r=0,92 за Спірменом та r=0,83 за Пірсоном).

На нашу думку, наявність від'ємної кореляції між ПФ та ПС ЗІК у динаміці спостереження свідчить про незмінність кількості елементів еферентної ланки рухової системи - мотонейронів та відповідних рухових одиниць, задіяних у реалізацію функції паретичної кінцівки; наявність додатньої кореляції або відсутність кореляції (слабка кореляція) свідчить про зміну в часі кількості охоплених супраспінальними впливами мотонейронів. Таке припущення випливає з очевидного факту: збільшення неконтрольованого тонусу м'яза обмежує реалізацію його усвідомленої функції, тобто залежне від вольового впливу, узгоджене в часі фазне скорочення та розслаблення під час здійснення поведінкового акту. Отже, за незмінності апарату іннервації м'яза, ПС та ПФ повинні проявляти від'ємну кореляцію, що певною мірою відображено на прикладі групи “стороннє тіло”. У групі “контроль” і, особливо, “нейрогель” відновний процес призводить до суттєвого послаблення (“контроль”) та нівелювання 
(“нейрогель”) такої кореляції, збільшуючи під час типового наростання спастичності кількість охоплених моно- чи полісинаптичними супраспінальними проекціями мотонейронів, тобто підвищуючи функціональну активність кінцівки шляхом, не залежним від послаблення спінальної дисрефлексії, всупереч наростанню спастичності.

Висновки. 1. Між ступенем спастичності, виміряним за шкалою Ashworth, та рівнем функції ЗІК, визначеним за шкалою ВВВ, на використаній моде-

\section{СПИСОК ЛІТЕРАТУРИ}

1. Sekhon L. H. S. Epidemiology, demographics, and pathophysiology of acute spinal cord injury [Text] / L. H. S. Sekhon, M.G. Fehlings // Spine (Phila Pa 1976). - 2001. - Vol. 26, Suppl 24. - P. 2-12.

2. Thuret S. Therapeutic interventions after spinal cord injury [Text] / S. Thuret, L. D. F. Moon, F. H. Gage // Nat. Rev. Neurosci. - 2006. - Vol. 7, No. 8. - P. 628-643.

3. The global map for traumatic spinal cord injury epidemiology: update 2011, global incidence rate / B. B. Lee, R. A. Cripps, M. Fitzharris, P. C. Wing // Spinal Cord. - 2014. - Vol. 52, No. 2. - P. 110-116.

4. Neurorehabilitation with neural transplantation [Text] / M. Döbrössy, M. Busse, T. Piroth [et al.] // Neurorehabil. Neural Repair. - 2010. - Vol. 24, No. 8. - P. 692-701.

5. Middendorp van J. J. The Edwin Smith papyrus: a clinical reappraisal of the oldest known document on spinal injuries [Text] / J. J. van Middendorp, G. M. Sanchez, A. L. Burridge // Eur. Spine J. - 2010. - Vol. 19, No. 11. - P. 1815-1823.

6. Spinal traumas and their treatments according to Avicenna's Canon of Medicine [Text] / F. Ghaffari, M. Naseri, M. Movahhed, A. Zargaran // World Neurosurg. - 2015. - Vol. 84, No. 1. P. 173-177.

7. Nowrouzi B. Spinal cord injury: a review of the most-cited publications / B. Nowrouzi // Eur. Spine J. - 2016 [Epub ahead of print].

8. Louie D. R. Gait speed using powered robotic exoskeletons after spinal cord injury: a systematic review and correlational study / D. R. Louie, J. J. Eng, T. Lam // J. Neuroeng. Rehabil. 2015. - Vol. 12. - P. 1-10.

9. López-Larraz E. Control of an ambulatory exoskeleton with a brain-machine interface for spinal cord injury gait rehabilitation / E. López-Larraz // Front. Neurosci. - 2016. - Vol. 10, Article 359. - P. 1-15.

10. Miller L. E. Clinical effectiveness and safety of powered exoskeleton-assisted walking in patients with spinal cord injury: systematic review with metaanalysis / L. E. Miller, A. K. Zimmermann, W. G. Herbert // Med. Devices (Auckl). 2016. - Vol. 9. - P. 455-466.

11. Assunção-Silva R. C. Hydrogels and cell based therapies in spinal cord injury regeneration [Text] / R. C. Assunção-Silva // Stem Cells International. - 2015. - Vol. 2015. - P. 1-24.

12. Siebert J. R. Biomaterial approaches to enhancing neurorestoration after spinal cord injury: strategies for overcoming inherent biological obstacles [Text] / J. R. Siebert, A. M. Eade, D. J. Osterhout // Bio. Med. Res. Int. - 2015. - Vol. 2015. P. 1-20.

13. Tsintou M. Advances in regenerative therapies for spinal cord injury: a biomaterials approach [Text] / M. Tsintou, K. Dalamagkas, A. M. Seifalian // Neural. Regen. Res. - 2015. Vol. 10, No. 5. - P. 726-742. лі спінальної травми не виявлено сильної від’ємної кореляції, притаманної випадку травми спинного мозку із тривалою персистенцією стороннього тіла; за умов результативної стимуляції регенерації спинного мозку виявлено додатну кореляцію обох показників при аналізі динаміки в часі.

2. Регенераційний процес суттєво видозмінює вид кореляції між ПФ та ПС ЗІК, ймовірно, шляхом збільшення елементної бази еферентної ланки рухової системи, контрольованої супраспінальними впливами.

14. Volpato F. Z. Using extracellular matrix for regenerative medicine in the spinal cord [Text] / F. Z. Volpato // Biomaterials. - 2013. - Vol. 34, No. 21. - P. 4945-4955.

15. Leach J. B. Bridging the divide between neuroprosthetic design, tissue engineering and neurobiology / J. B. Leach, A. K. H. Achyuta, S. K. Murthy // Front. Neuroeng. - 2010. - Vol. 2. - P. 1-19.

16. Maynard F. M. Epidemiology of spasticity following traumatic spinal cord injury / F. M. Maynard, R. S. Karunas, W. P. Waring // Arch. Phys. Med. Rehabil. - 1990. - Vol. 71, No. 8. - P. 566-569.

17. Skold C. Spasticity after traumatic spinal cord injury: nature, severity, and location [Text] / C. Skold, R. Levi, A. Seiger // Phys. Med. Rehabil. - 1999. - Vol. 80, No. 12. - P. 1548-1557. 18. Walters J. S. A database of self-reported secondary medical problems among VA spinal cord injury patients: its role in clinical care and management [Text] / J. S. Walters // J. Rehabil. Res. Dev. - 2002. - Vol. 39, No. 1. - P. 53-61.

19. Longitudinal changes in medical complications in adults with pediatric-onset spinal cord injury [Text] / M. Hwang, K. Zebracki, K. M. Chlan, L. C. Vogel // J. Spinal Cord Med. - 2014. - Vol. 37, No. 2. - P. 171-178.

20. Murray K. C. Recovery of motoneuron and locomotor function after spinal cord injury depends on constitutive activity in 5-HT ${ }_{2 C}$ receptors [Text] / K. C. Murray // Nature Med. - 2010. Vol. 16, No. 6. - P. 694-701.

21. Heckman C. J. Motor unit [Text] / C. J. Heckman, R. M. Enoka // Compr. Physiol. - 2012. - Vol. 2, No. 4. - P. 2629-2682.

22. Recovery of neuronal and network excitability after spinal cord injury and implications for spasticity [Text] / J. M. D'Amico, E. G. Condliffe, K. J. B. Martins [et al.] // Front. Int. Neurosci. 2014. - Vol. 8. - P. 1-24.

23. Di Narzo A. F. Decrease of mRNA editing after spinal cord injury is caused by down-regulation of ADAR2 that is triggered by inflammatory response [Text] / A. F. Di Narzo // Sci. Rep. 2015. - Vol. 5. - P. 1-15.

24. Pandyan A. D. A review of the properties and limitations of the Ashworth and modified Ashworth Scales as measures of spasticity [Text] / A. D. Pandyan // Clin. Rehabil. - 1999. Vol. 13, No. 5. - P. 373-383.

25. Bakheit A. M. O. The relation between Ashworth scale scores and the excitability of the $\alpha$ motor neurones in patients with poststroke muscle spasticity [Text] / A. M. O. Bakheit // J. Neurol. Neurosurg. Psychiatry. - 2003. - Vol. 74. - P. 646-648.

26. Biering-Sørensen F. Spasticity-assessment: a review [Text] / F. Biering-Sørensen, J. B. Nielsen, K. Klinge // Spinal Cord. 2006. - Vol. 44. - P. 708-722.

27. Nielsen J. B. The spinal pathophysiology of spasticity - from a basic science point of view [Text] / J. B. Nielsen, C. Crone, H. Hultborn // Acta. Physiol. (Oxf). -2007. - Vol. 189, No. 2. P. 171-180. 


\section{ЕКСПЕРИМЕНТАЛЬНІ ДОСЛІДЖЕННЯ}

28. Malhotra S. Spasticity, an impairment that is poorly defined and poorly measured [Text] / S. Malhotra // Clin. Rehabil. - 2009. - Vol. 23, No. 7. - P. 651-658.

29. Roy R. R. Neurobiological perspective of spasticity as occurs after a spinal cord injury / R. R. Roy, V. R. Edgerton // Exp. Neurol. - 2012. - Vol. 235. - P. 116-122.

30. Strain and model differences in behavioral outcomes after spinal cord injury in rat / C. D. Mills, B. C. Hains, K. M. Johnson, C. E. Hulsebosch. // J. Neurotrauma. - 2001. - Vol. 18, No. 8. P. 743-756.

31. Decreased dynorphin A (1-17) in the spinal cord of spastic rats after the compressive injury [Text] / H. W. Dong, L. H. Wang, M. Zhang, J. S. Han // Brain Res. Bull. - 2005. - Vol. 67, No. 3. - P. 189-195.

32. Majczynski H. Locomotor recovery after thoracic spinal cord lesions in cats, rats and humans / H. Majczynski, U. Slawinska // Acta Neurobiol. Exp. (Wars). - 2007. - Vol. 67, No. 3. - P. 235257.

33. Spontaneous recovery of hindlimb movement in completely spinal cord transected mice: a comparison of assessment methods and conditions / R. V. Ung, N. P. Lapointe, C. Tremblay [et al.] // Spinal Cord. - 2007. - Vol. 45, No. 5. - P. 367-379.

34. Motor deficits and recovery in rats with unilateral spinal cord hemisection mimic the Brown-Sequard syndrome / L. Filli, B. Zörner, O. Weinmann, M. E. Schwab // Brain. - 2011. Vol. 134, Pt. 8. - P. 2261-2273.

35. Vierck C. J. Evaluation of lateral spinal hemisection as a preclinical model of spinal cord injury pain / C. J. Vierck, R. L. Cannon, A. J. Acosta-Rua // Exp. Brain Res. - 2013. Vol. 228, No. 3. - P. 305-312.

36. Hahm S. C. High-frequency transcutaneous electrical nerve stimulation alleviates spasticity after spinal contusion by inhibiting activated microglia in rats [Text] / S. C. Hahm, Y. W. Yoon, J. Kim // Neurorehabil. Neural Repair. - 2015. Vol. 29, No. 4. - P. 370-381.

37. Spinal shock revisited : a four-phase model [Text] / J. F Ditunno, J. W. Little, A. Tessler, A. S. Burns // Spinal Cord. - 2004. - Vol. 42, No. 7. - P. 383-395.

38. Цымбалюк В. И. Спинной мозг. Элегия надежды / В. И. Цымбалюк, В. В. Медведев. - Винница : Нова Книга, 2010. - 944 с.

39. Модель пересічення половини поперечника спинного мозку. Ч. І. Технічні, патоморфологічні та клініко-експериментальні особливості / В. І. Цимбалюк, В. В. Медведєв, В. М. Семенова [та ін.] // Укр. нейрохірург. журнал. - 2016. № 2. - C. 18-27.

Отримано 07.09.16 